\title{
PERFORATION AS A COMPLICATION OF THE DIAGNOSTIC UPPER AND LOWER ENDOSCOPY OF THE GASTROINTESTINAL TRACT
}

\author{
Ivailo P. Vazharov, \\ Department of Gastroenterology; \\ Multiprofile Hospital for Active Treatment - Varna; \\ Military Medical Academy - Sofia, Bulgaria
}

\begin{abstract}
:
Purpose: The purpose of this examination is to evaluate the risk of perforation during endoscopy of upper and lower gastrointestinal tract.

Patients and methods used: 1210 diagnostic gastroduodenoscopies and 412 colonoscopies of hospitalized patients were performed by two experienced endoscopists for the period March 2007 - March 2012 at MHAT - Varna, MMA. The endoscopies were performed without premedication and sedation. The patients were examined for complications of the procedure during and after the endoscopy. One of the most serious complications is the perforation of the oesophagus, stomach or the large intestine.
\end{abstract}

Results: We had no perforations caused by the examination during the 1210 upper endoscopies performed. We had 2 perforations $(0,48 \%)$ from the 412 colonoscopies performed, which were treated successfully surgically.

Conclusions: The perforation is a rare but serious complication of the endoscopy of gastrointestinal tract, which can be healed completely.

Key words: gastroduodenoscopy, colonoscopy, perforation.

\section{INTRODUCTION:}

The perforation is second most common complication of diagnostic upper and lower endoscopy.(1) The predisposing factors of this complication of gastroduodenoscopy are the corrosive esophagites as well as the presence of anterior cervical osteophytes, Zenker's and epiphrenic diverticula, strictures of oesophagus, disintegrated tumor, senile patients ( $>72$ years old).(2) The predisposing factors during colonoscopy are altered intestinal mucosa (chronic ulcerative - hemorrhagic colitis, disease of Crohn, diverticulosis, cancer and generalized polyposis with secondary inflammation), diverticulosis of the intestine, patients of senile age, patients with a previous abdominal surgical intervention.(3) The lack of experience of the specialist is also a risk factor.(4) The most common localization of the perforation in lower endoscopy is sigma $/ 80 \%$ /, followed by transversal large intestine (13\% )(5), the region of pharynx and cardia in upper endoscopy. /6/ The incidents with perforations of colon in extensive studies (> 30000 cases) vary from $0,031 \%(7)$ to $0,090 \%(8)$, and in upper endoscopy $-0,05 \%$.(9)

\section{PATIENTS AND METHODS USED:}

1210 diagnostic gastroduodenoscopies (725 men and 485 women) were performed by two experienced endoscopists for the period March 2007 - March 2012 at MHAT - Varna, MMA. The average age of the patients was 55 years, the minimum one -18 years, and the maximum one was 77 years. The colonoscopies were 412 for the same period. The average age of the patients was 65 years, the minimum one - 38 years, and the maximum one was 80 years. The endoscopies were performed without premedication and sedation. The endoscopies were performed before meal, cleaning of the large intestine with 2 sachets Endofalk diluted in 2 litres water the day before colonoscopy, without enema. The patients were observed for complications of the procedure during and after the endoscopy. One of the most serious complications is the perforation of the oesophagus, stomach or the large intestine.

The following definitions of perforation were used:

a) in colonoscopy: visualization of extra intestinal structure / omentum, liver, intestines /, presence of pneumoperitoneum or retroperitoneal gas with symptoms of peritonitis after endoscopy and intraoperative finding of perforated colon.(10)

b) in oesophagogastroduodenoscopy: pain in the chest, pneumomediastinum with the corresponding symptoms, temperature, crepitation, pleural pain, leukocytosis, pleural effusion after upper endoscopy.(11)

\section{RESULTS:}

There were no perforations caused by the examination during the 1210 upper endoscopies performed. 25 of them were performed for diagnostics and staging of corrosive oesophagitis and gastritis. We had 2 perforations 
$(0,48 \%)$ from the 412 colonoscopies performed, and they were diagnosed within 3 hours after the examination. They were in the region of sigma, there was no effusion of intestinal contents in the abdominal cavity and were treated successfully surgically.

\section{DISCUSSION:}

The upper and lower gastrointestinal endoscopies are frequently performed procedures for diagnostics of patients with a wide range of problems and complaints.(12) The diagnostic is an invasive method and it bears $\backslash$ a risk for the patient.(13) The present-day literature suggests that these examinations have mainly cardiorespiratory complications and the other complications perforation including are very rare.(14) This corresponds to the results of our study, where we have no perforation during upper endoscopy, although it was performed in 25 patients with erosive oesophagitis, which is the main predisposing factor of its occurrence.(15) We performed early endoscopy in these patients (24 - 48 hours after the burn) for evaluation of the degree of the burn and the necessary treatment conservative or operative.

We had a rate of $0,48 \%$ perforations in colono- scopies, which corresponds to the literary data.(17) The active follow up of the patients during and after the examination is a necessary precondition for early diagnosis and adequate therapy of this serious complication. The perforation may be diagnosed several days after the endoscopy.(18) We had diverticula in the region of sigma in both perforations, which is the major predisposing factor. /19/ The rupture of the wall can be caused by mechanical pressure on the intestinal wall or a barotrauma.(20)

Both perforations were treated surgically. The question which approach of treatment is more successful conservative or operative, is debatable.(21) The opinion that the choice of treatment depends on the size of the lesion outweighs.(22) The surgical treatment is appropriate when the perforation occurs during diagnostic colonoscopy, because there are large ruptures of the colon in these cases. Non surgical treatment is justified after polypectomy if there is a quick clinical improvement.(23)

\section{CONCLUSIONS:}

The perforation is a rare but serious complication of the endoscopy of gastrointestinal tract, which can be healed completely when timely diagnosed.

\section{REFERENCES:}

1. Cobb WS, Heniford BT, Sigmon LB, Hasan R, Simms C, Kercher KW, et al. Colonoscopic perforations: incidence, management and outcomes. Am Surg. 2004 Sep;70(9):750-7. [PubMed]

2. Lanas A, Garcia-Rodriguez LA, Polo-Tomas M, Ponce M, AlonsoAbreu I, Perez-Aisa MA, et al. Time trends and impact of upper and lower gastrointestinal bleeding and perforation in clinical practice.et al. $A m J$ Gastroenterol. 2009 Jul;104(7):1633-41. [PubMed] [CrossRef]

3. Castellvi J, Pi F, Sueiras A, Vallet J, Bollo J, Tomas A, et al. Colonoscopic perforation: useful parameters for early diagnosis and conservative treatment. Int J Colorectal Dis. 2011 Sep;26(9): 1183-90. [PubMed] [CrossRef]

4. Panteris V, Haringsma J, Kuipers EJ. Colonoscopy perforation rate, mechanisms and outcome: from diagnostic to therapeutic colonoscopy. Endoscopy. 2009 Nov;41(11):941-51. [PubMed] [CrossRef]

5. Lohsiriwat V, Sujarittanakarn S, Akaraviputh T, Lertakyamanee N,
Lohsiriwat D, Kachinthorn U. Colonoscopic perforation: A report from World Gastroenterology Organization endoscopy training center in Thailand. World J Gastroenterol. 2008 Nov 21; 14(43):6722-5. [PubMed]

6. Eroglu A, Turkyilmaz A, Aydin Y, Yekeler E, Karaoglanoglu N. Current management of esophageal perforation: 20 years experience. Dis Esophagus. 2009; 22(4):374-80. [PubMed] [CrossRef]

7. Korman LY, Overholt BF, Box T, Winker CK. Perforation during colonoscopy in endoscopic ambulatory surgical centers. Gastrointest Endosc. 2003 Oct;58(4): 554-7. [PubMed] [CrossRef]

8. Arora G, Mannalithara A, Singh G, Gerson LB, Triadafilopoulos G. Risk of perforation from a colonoscopy in adults: a large population-based study. Gastrointest Endosc. 2009 Mar;69(3 Pt 2):654-64. [PubMed] [CrossRef]

9. Quine MA, Bell GD, McCloy RF, Matthews HR. Prospective audit of perforation rates following upper gastrointestinal endoscopy in two regions of England. Br J Surg. 1995 Apr;82(4):530-3. [PubMed]

10. Lohsiriwat V, Sujarittanakarn S, Akaraviputh $\mathrm{T}$, Lertakyamanee $\mathrm{N}$, Lohsiriwat D, Kachinthorn U. What are the risk factors of colonoscopic perforation? BMC Gastroenterol. 2009 Sep 24;9:71. [PubMed]

11. American Society for Gastrointestinal Endoscopy; Eisen GM, Baron TH, Dominitz JA, Faigel DO, Goldstein JL, Johanson JF, et al. Complications of upper GI endoscopy. Gastrointestinal Endoscopy. 2002 Jun;55(7): 784-793. [PubMed]

12. Cho SB, Lee WS, Joo YE, Kim HR, Park SW, Park CH, et al. Therapeutic options for iatrogenic colon perforation: feasibility of endoscopic clip closure and predictors of the need for early surgery. Surg Endosc. 2012 Feb;26(2):473-9. [PubMed] [CrossRef]

13. Jafri SM, Monkemuller K, Lukens FJ. Endoscopy in the elderly: a review of the efficacy and safety of colonoscopy, esophagogastroduodenoscopy, and endoscopic retrograde 
cholangiopancreatography. J Clin Gastroenterol. 2010 Mar;44(3):161-6. [PubMed] [CrossRef]

14. Palmer KR. Complications of gastrointestinal endoscopy. Gut. 2007 Apr;56(4):456-457. [PubMed]

15. Singhal S, Kar P. Corrosive injuries of esophagus and stomach issues in management. Trop Gastroenterol. 2006 Jan-Mar;27(1):34-40. [PubMed]

16. Robustelli U, Bellotti R, Scardi F, Fortunato Armellino M, De Masi A, Forner AL, et al. Management of corrosive injuries of the upper gastrointestinal tract. Our experience in 58 patients. G Chir. 2011 Apr;32(4):188-93. [PubMed]

17. Luning $\mathrm{TH}$, Keemers-Gels ME, Barendregt WB, Tan AC, Rosman C.
Colonoscopic perforations: a review of 30,366 patients. Surg Endosc. 2007 Jun;21(6):994-7. [PubMed] [CrossRef]

18. Araujo SE, Seid VE, Caravatto PP, Dumarco R. Incidence and management of colonoscopic colon perforations: 10 years' experience. Hepatogastroenterology. 2009 Nov-Dec; 56(96):1633-6. [PubMed]

19. Loffeld RJ, Engel A, Dekkers PE. Incidence and causes of colonoscopic perforations: a single-center case series. Endoscopy. 2011 Mar;43(3):240242. [PubMed] [CrossRef]

20. Makharia GK, Madan K, Garg PK, Tandon RK. Colonoscopic barotrauma treated by conservative management: role of high-flow oxygen inhalation. Endoscopy. 2002 Dec;34(12): 1010-3. [PubMed] [CrossRef]
21. Jovanovic I, Zimmermann L, Fry LC, Monkemuller K. Feasibility of endoscopic closure of an iatrogenic colon perforation occurring during colonoscopy. Gastrointest Endosc. 2011 Mar;73(3):550-5. [PubMed] [CrossRef]

22. Chao TH, Wang HM, Liou TY et al Clinical treatment in colonoscopic perforation: a comparison of surgical and conservative management. Zhonghua-Yi-Xue-Za-Zhi-(Taipei). 1997; 60(1): 36-9. [PubMed]

23. Garcia Martinez MT, Ruano Poblador A, Galan Raposo L, Gay Fernandez AM, Casal Nunez JE. Perforation after colonoscopy: our 16year experience. Rev Esp Enferm Dig. 2007 Oct;99(10):588-92. [PubMed]

\section{Corresponding author:}

Ivailo P. Vazharov

Multiprofile Hospital for Active Treatment - Varna, Military Medical Academy, 84, Oditel str., Varna, Bulgaria

E-mail: vajarov@dir.bg 